\title{
Heterogeneity of sickle cell anaemia in Arabs: review⿳亠二口犬 of cases with various amounts of fetal haemoglobin
}

\author{
KARIM KAMEL \\ From the Department of Pathology and Blood Transfusion Service, The Military Hospital, UAE Armed \\ Forces Medical Services, Abu Dhabi, United Arab Emirates
}

SUMMARY A study is presented on eleven patients with homozygous sickle cell anaemia. They ate non-Sheeah Arabs from the United Arab Emirates on the south-eastern coast of the Arabiam Peninsula. The proportions of fetal haemoglobin in these patients are variable, and there is a marked variation in the severity of their disease condition; these facts are not related. African sickle cell gere admixture is a likely affecting factor.

In 1972, Perrine et al. reported the condition of 'benign sickle cell anaemia' in 18 Arabs. The patients were Saudis of the Shiite (Sheeah) religious sect of Islam from Al Qateef and Al Hasa oases on the eastern coast of the Arabian Peninsula, and the mildness of their disease was ascribed to a high proportion of fetal haemoglobin (Hb F). This was later proved not to be the result of coexistent glucose-6-phosphate dehydrogenase (G6PD) deficiency, $\alpha$-thalassaemia trait, or hereditary persistence of fetal haemoglobin, but was rather a genetically determined condition of an absolute increase in $\mathrm{Hb} \mathrm{F}$ production related to their homozygous sickle cell anaemia (Pembrey et al., 1978; Perrine et al., 1978).

This is a presentation of another group of sickle cell anaemia patients in non-Sheeah Arabs of nearby Abu Dhabi, capital of the United Arab Emirates (UAE) on the south-eastern coast of the Arabian Peninsula. Some of the patients reviewed here also have increased $\mathrm{Hb} F$ production, and some do not, and the heterogeneity of their clinical and haematological conditions is manifest.

\section{Materials and methods}

The subjects, eleven in number, are Arabs and their families have lived in this part of the world for as long as they know. They are not Sheeah. The patients are dependants of military personnel who were referred to the Haematology Division of the Pathology Department of the Abu Dhabi Military Hospital for haematological assessment over the last 4 years. This Division serves patients, both military

Received for publication 23 March 1979 and civilian, with haematological problems fro $\vec{m}$ the seven Emirates that make up the Federal Uniog

The following determinations were carried out of all the patients and on both parents of each of patients No $1,3,5,8,9$, and 11 (Table). The rest of the parents could not be examined. The tests werres complete blood counts including reticulocese haemoglobin electrophoresis on cellulose acefate medium in tris EDTA borate buffer at $\mathrm{pH}$. sodium metabisulphite sickling preparation, ${ }^{+}$a. done by standard techniques (Dacie and Lewi 1975), and solubility test for $\mathrm{Hb} \mathrm{S}$ using a commerciont kit (Sickledex). Alkaline denaturation test for $\mathrm{Hb}$ 亩 was made by the method of Singer et al. (1951). $\mathrm{Hb} \mathrm{A_{2 }}$ was estimated by the technique of Weathera and Clegg (1972), a modification of that of Mareng Rowe (1965). Screening for G6PD deficiency was performed by the UV fluorescent spot test of Beutler (1966) using Sigma ready reagents.

Table Haematological and clinical data on 11 nonSheeah Arabs with sickle cell anaemia

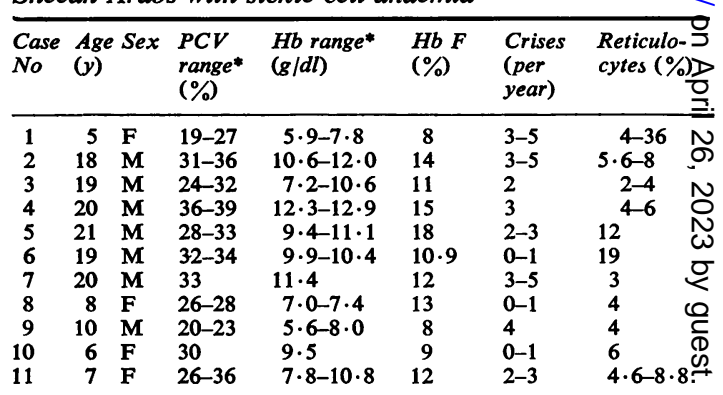

*Where only one value is given, the patient could not be examing more than once. 
Results

The results of the above determinations are given in the Table. G6PD deficiency was excluded in all subjects tested, and $\mathrm{Hb} \mathrm{A}_{2}$ was within the normal range in them all.

\section{Discussion}

All patients had homozygous sickle cell anaemia with $\mathrm{Hb}$ type $\mathbf{S S}+\mathbf{F}$ and the tested parents had sickle cell traits with $\mathrm{Hb} \mathrm{A}+\mathrm{S}$. G6PD deficiency in Abu Dhabians is expressed by a $G^{-}$gene frequency of $0 \cdot 1000$ and they are usually symptomless (Kamel et al., 1979), either because of a genetic determination or because of the absence of the challenging oxidant. It was not a superadded factor in the patients reported here, since none was G6PD deficient by the screening test.

The prevalence of some thalassaemia syndromes is high in certain Saudi Arabs (Pembrey et al., 1975). In the present population, the incidence of various thalassaemias is not known. It is of significance, however, that over the last 4 years, only two cases of classical $\beta$-thalassaemia major were confirmed in this department among the indigenous population. One of these was from Abu Dhabi Emirate, and the other was from Um Al-Quwain Emirate, with populations of about 80000 and 10000 , respectively (Ramahi, 1973). $\mathrm{Hb} \mathrm{A_{2 }}$ was not raised in any of the people reported here, and a survey on $\mathrm{Hb}$ variants only showed $\mathrm{Hb} \mathrm{S}$ among Abu Dhabians (Kamel et al., 1979).

It is worthy of note that in three of the eleven patients (No 1, 8, and 9), the haemoglobin ( $\mathrm{Hb})$ level had stabilised at less than $8.0 \mathrm{~g} / \mathrm{dl}$, and that in another two cases (No 3 and 11) the Hb level was often below $8.0 \mathrm{~g} / \mathrm{dl}$. The number of crises or infections or both necessitating admission to hospital varied from 0 to 5 per year, and two cases (No 1 and 9) required transfusions at least once a year. It is interesting that patients No 4 and 9 , in addition to their sickle cell anaemia, had Plasmodium falciparum infection. Four patients (No 2, 4, 5, and 7) at some time had a $\mathrm{Hb}$ level over $11.0 \mathrm{~g} / \mathrm{dl}$ without transfusion and thus did not qualify at those times for the diagnosis of anaemia as defined by the World Health Organization in 1968. Two cases (No 6 and 10) were moderate in severity at a $\mathrm{Hb}$ level ranging from 9.5 to $10.4 \mathrm{~g} / \mathrm{dl}$. None of the patients had leg ulcers nor scars from them.

$\mathrm{Hb} \mathrm{F}$ ranged from 8 to $18 \%$ with a mean of $11.9 \%$ and within this range there was no correlation between its leveland the patients' clinical manifestations. $\mathrm{Hb} F$ percentage in the reported patients falls mid- way between that of the Sheeah and Jamaican levels (Perrine et al., 1972).

The patients presented here have been 'selected' in that they were referred patients and their number is obligatorily small because of the small Abu Dhabian population and the relatively low frequency of $\mathrm{Hb} \mathrm{S}$ gene of 0.0120 (Kamel et al., 1979). They nevertheless illustrate the presence of a wide range of severity of clinical manifestations of homozygous sickle cell anaemia in some Arabs who also have varying amounts of $\mathrm{Hb} \mathrm{F}$. However, this series should not imply the non-existence of very mild cases of benign sickle cell anaemia patients in the same community who did not come for haematological advice. Four of the eleven patients should indeed be classified as benign.

The Sheeah, the sect of Islam introduced in Iraq in the 7th century, only predominate in Iran, Iraq, Pakistan, and Bahrain. Elsewhere in the Islamic nations, the overwhelming majority are Sunnis. Some Hinnawi tribes in the Sultanate of Oman, which is adjacent to the UAE, are of the Ibadhi sect, differing from both Sunnis and Sheeah (Phillips, 1971). Except where mentioned above, the Sheeah are clustered in isolated foci forming good opportunities for inbreeding. This may have been a causative factor in the abundance of benign cases of sickle cell anaemia reported.

Although the patients reviewed here are Arabs in origin, intermixing with African sickle cell gene is a likely event since (1) there is debate about whether the sickle cell gene originated in Africa or Asia (Kamel and Awny, 1965); (2) the slave trade market (from Africa) was a flourishing business until the British treaties with the Trucial Coast authorities between 1839 and 1856 (Abdullah, 1978); and (3) the Coast of Oman (later called the Trucial Coast) historically dominated most East African territories and islands.

\section{References}

Abdullah, M. M. (1978). The United Arab Emirates. A Modern History, p. 38. Harper and Row, USA.

Beutler, E. (1966). A series of new screening procedures for pyruvate kinase deficiency, glucose-6-phosphate dehydrogenase deficiency, and glutathione reductase deficiency. Blood, 28, 553-562.

Dacie, J. V., and Lewis, S. M. (1975). Practical Haematology, 5th ed., pp. 238-243. Churchill Livingstone, Edinburgh, London, New York.

Kamel, K., and Awny, A. (1965). Origin of the sickling gene. Nature, 205, 919.

Kamel, K., Chandy, R., Mousa, H., and Yunis, D. (1979). Blood groups and types, hemoglobin variants and G-6-PD deficiency among Abu Dhabians in the United Arab Emirates. American Journal of Physical Anthropology. (In press.)

Marengo-Rowe, A. J. (1965). Rapid electrophoresis and 
quantitation of haemoglobins on cellulose acetate. Journal of Clinical Pathology, 18, 790-792.

Pembrey, M. E., Weatherall, D. J., Clegg, J. B., Bunch, C., and Perrine, R. P. (1975). Haemoglobin Bart's in Saudi Arabia. British Journal of Haematology, 29, 221-235.

Pembrey, M. E., Wood, W. G., Weatherall, D. J., and Perrine, R. P. (1978). Fetal haemoglobin production and the sickle gene in the oases of eastern Saudi Arabia. British Journal of Haematology, 40, 415-429.

Perrine, R. P., Brown, M. J., Clegg, J. B., Weatherall, D. J., and May, A. (1972). Benign sickle-cell anaemia. Lancet, 2, 1163-1167.

Perrine, R. P., Pembrey, M. E., John, P., Perrine, S., and Shoup, F. (1978). Natural history of sickle cell anemia in Saudi Arabs. A study of 270 subjects. Annals of Internal Medicine, 88, 1-6.

Phillips, W. (1971). Unknown Oman, p. 23. Librairie du Liban, Beirut.
Ramahi, S. A. (1973). Economics and Political Evolution in the Arabian Gulf States, p. 45. Carlton Press, New York.

Singer, K., Chernoff, A., and Singer, L. (1951). Studies of: abnormal hemoglobins. 1. Their demonstration in sickl $\vec{e}$ cell anemia and other hematologic disorders by means off alkali denaturation. Blood, 6, 413-428.

Weatherall, D. J., and Clegg, J. B. (1972). The Thalassaemiā Syndromes, 2nd ed., p. 311. Blackwell Scientific Publion cations, Oxford.

World Health Organization (1968). Nutritional anemias? Report of a WHO Scientific Group. WHO Technica出 Report Series, 405, 9.

Requests for reprints to Professor Karim Kamel 56 Muhammad Mazhar Street, Zamalek, Cairo? Egypt. 